Eliisa Vainikka

\section{AVAIMIA NETTIMEEMIEN TULKINTAAN Meemit transnationaalina mediailmiönä}

Artikkelissa tarkastellaan suomalaisella Ylilauta-keskustelufoorumilla esiintyneitä meemikuvia transnationaalin mediakierron kehyksessä. Meemin käsite on viime aikoina levinnyt verkon alakulttuureista yhä enemmän valtajulkisuuteen, mikä nostaa osaltaan meemit esiin kiinnostavana mediakulttuurin tutkimuskohteena. Artikkelin varsinaisena analyysin kohteena ovat kaksi meemiä - "Sad Frog" ja "Liekkipipo ja pirikiikarit" -, joissa sekoittuu elementtejä suomalaisesta ja kansainvälisestä verkkokulttuurista.

Nettipoliisi Marko "Fobba" Forss latasi keväällä 2016 Facebook-profiilinsa taustakuvaksi nettimeemeihin viittaavan kuvan, jossa poliisiautoa esittävä leikkiauto kyyditsee paperista askarreltuja "Spurdo Spärde"1 -meemihahmoja. Kuva keräsi paljon tykkäyksiä ja kommentteja mutta aiheutti myös hämmennystä: osa kommentoijista sekoitti kuvan tunnettuun "Pedobear"meemiin, pedofiiliä esittävään hymyilevään karhuhahmoon, joka on saanut alkunsa 4chan-foorumilla. Verkkokulttuurin tuntijat kuitenkin kiirehtivät huomauttamaan paheksujille, että kyseessä ei ole Pedobear vaan suomalaisperäinen Spurdo Spärde -hahmo, joka syntyi monimutkaisten vaiheiden kautta kuvalautojen alakulttuurissa energiajuomia litkivää esiteini-ikäistä nuorta miestä kuvaavaksi "Jonneksi". Myöhemmin Spurdo-hahmosta kehittyi edelleen valikoima netissä kiertäviä hahmoja, kuten "Alikersantti Spurdo" ja "Le American Bear".

Internetissä kiertäviä meemejä ja puhetapoja - samoin kuin suomalaisen verkkokulttuurin merkityksiäkin - on tärkeä tutkia, jotta kulttuurintutkimuksessa pystyttäisiin seuraamaan, mille pohjalle ja millä tavoin kielelliset ja visuaaliset merkitykset rakentuvat. Internetmeemeihin liittyvät merkitykset leviävät osittain muistitietona, kuten kansanperinne, jossa saman tarinan versioita usein kerrotaan hieman eri tavoin. Esimerkiksi Onerva Lepistö (2016) mainitsee artikkelissaan "Vauhtilasit ja vauhtipipo"-meemin. Sama meemi tunnetaan myös nimellä Liekkipipo ja pirikiikarit.

Merkitysten sekoittuminen ja leviäminen hämmentävät yleisöjä, kuten Fobban taustakuvan tapaus osoittaa. Nettimeemit ovat monitulkintainen vies-
Eliisa Vainikka, FM

COMET - Journalismin, viestinnän ja median tutkimuskeskus, Tampereen yliopisto

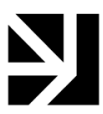

VERTAISARVIOITU KOLLEGIALT GRANSKAD PEER-REVIEWED

1 "Spurdo Spärde" on suomalaisilta verkkofoorumeilta kiertoon lähtenyt huonosti piirretty imitaatio tunnetusta "Pedobear"-meemistä, joka on lähtenyt elämään omaa elämäänsä kuvalautojen kansanperinteessä. 
tinnän muoto, ja meemien avulla pyritään myös tahallisesti hämmentämään. Siitä huolimatta meemejä käytetään yhä useammin julkisen keskustelun kommentointiin. ${ }^{2}$ Nettimeemit ovat myös tunteenomainen ja poliittinen ilmaisumuoto (Shifman 2014, 119-150; Esteves 2014; Burnett \& al. 2014). Poliitikoille irvailun lisäksi meemejä voidaan huomioarvonsa takia valjastaa esimerkiksi poliittisten tai kaupallisten päämäärien ajamiseen (ks. esim. Vainikka 2016; Rodley 2016). Meemit eivät enää kuulukaan ainoastaan verkon alakulttuureihin. Ne leviävät digitaalisen teknologian avustuksella yhteiskunnan eri alueille vaikuttaen eri tavoin eri paikoissa ja erilaisilla verkkoalustoilla -kuten Facebookissa kiertävinä poliittisina meemeinä.

Artikkeli alkaa katsauksella meemin käsitteeseen ja muutamiin viimeaikaisiin meemeistä tehtyihin tutkimuksiin. Analysoin tarkemmin kahta meemikuvaa-Sad Frog ja Liekkipipo ja pirikiikarit - pohtien, millä tavoin ne asettuvat osaksi toisaalta transnationaalia ja toisaalta paikallista verkkokulttuuria. Globaali meemikulttuuri tuottaa helposti myös kansallisia versioita suosituista meemeistä (Saarikoski 2016). Pyrin määrittelemään tässä artikkelissa meemien keskeisiä ominaisuuksia ja niiden tehtäviä verkkokeskusteluissa.

Tutkimuskysymykseni ovat: Millä tavoin netin meemikuvat asettuvat osaksi yhtäältä transnationaalia ja toisaalta paikallista verkkokulttuuria? Miten verkon meemikuvia voidaan analysoida? Miten meemikuvat merkityksellistyvät sen nimenomaisen verkkotilan kontekstissa, jossa ne esiintyvät? Artikkelin lopuksi teen yhteenvedon siitä, minkälaisia kysymyksiä meemikuvia analysoitaessa olisi syytä jatkossa esittää. Käytän analyysin laajempana kehyksenä keskustelua sisältöjen transnationaalista kierrosta globaalissa mediakulttuurissa.

\section{Meemin käsitteestä}

Meemillä (Dawkins 1976) tarkoitetaan yksittäistä kulttuurista sisältöä, joka leviää ihmisten välillä kopioinnin ja matkimisen kautta. Kirjassaan Memes in Digital Culture (2014) mediatutkija Limor Shifman selittää perinpohjaisesti meemi-käsitteen synnyn sekä pyrkii korostamaan ihmisen toimintaa meemien synnyssä ja kierrättämisessä. Termin taustalla vaikuttaa kuitenkin biologilta lainattu käsite. Biologi Richard Dawkins pyrki meemin käsitteellä kuvaamaan evoluutiota kulttuurisena, ei biologisena ilmiönä. Meemi on Dawkinsin määritelmässä kulttuurinen idea, joka pyrkii monistumaan ja leviämään. (Wiggins \& Bowers 2015.)

Limor Shifman haluaa tuoda meemin käsitteen viestinnän tutkimukseen, koska viestintäympäristömme toimintalogiikka on muuttunut käyttäjälähtöisen sisällön myötä. Shifman kääntää Richard Dawkinsin (1976) alkuperäisen meemi-käsitteen päälaelleen ja toteaa, että nettimeemit tulisi ymmärtää yksittäisten ideoiden sijaan ryhminä. Shifmanin mukaan nettimeemi voidaan määritellä ryhmäksi digitaalisen sisällön yksiköitä, joilla on yhteisiä sisällöllisiä, muodollisia tai asenteellisia piirteitä. Nämä sisältöyksiköt on tuotettu tietoisina toinen toisistaan. Niitä on kierrätetty, matkittu ja ne ovat muuttuneet kulkiessaan useiden eri käyttäjien kautta (Shifman 2014, 41).

Shifmanin määritelmässä korostuu se, miten vaikea meemejä on määritellä yksiselitteisesti, koska ne ovat jo lähtökohtaisesti olemukseltaan monenkirjavia. Huumorina nettimeemit ovat jossain mielessä sukua sekä sähköpostin välityksellä levitettäville humoristisille kiertokirjeille ja vitseille (Hokkanen 2015; Aro \& Sarpavaara 2007) että poliittisille pilapiirroksille. Meemihuumori
2 Esimerkiksi syyskuussa 2015 MTV nosti esiin lakonuhkaa kommentoivia nettimeemejä julkaisemalla artikkelin: "Some räjähti - tässä hulvattomimmat lakkomeemit" (MTV uutiset 2015). 
kuitenkin eroaa näistä ainakin siten, että se sisältää usein satunnaisia ja "dadaistisiakin" elementtejä, jotka ovat peräisin verkon nuoriso- ja alakulttuureista (ks. esim. Lepistö 2016). Meemit eivät kuitenkaan ole vain ja ainoastaan huumoriin liittyviä. Niihin ei välttämättä sisälly vitsiä, eivätkä kaikki meemit ole tunnerekisteriltään hauskoja, kuten esimerkiksi myöhemmin analysoimani Sad Frog -meemi

Meemin käsitteellä ei viitata välttämättä verkossa leviävään meemiin, vaikka arkikielessä sana onkin yleistynyt tarkoittamaan nettimeemiä. Nettimeemit ovat viestintää ja internetkulttuurin kollektiivista kulttuurista pääomaa (Fernback 2003), postmodernia kansanperinnettä, joka voi myös heijastaa piileviä sosiokulttuurisia rakenteita (Shifman 2014, 15). Nettimeemien kierto verkkokulttuurissa rakentaa yhteenkuuluvuutta käyttäjien välille ja samaistumista määrättyyn verkkoyhteisöön (Nakamura 2014, 269).

Kuten Shifman $(2014,34)$ kirjoittaa, ladatessaan, jakaessaan ja kuluttaessaan meemejä eri verkkoyhteisöjen käyttäjät samalla sekä ilmaisevat että rakentavat yksilöllisyyttään ja kuuluvuuttaan kyseiseen yhteisöön. Esimerkiksi valitessaan Spurdo-meemikuvan profiilinsa taustakuvaksi nettipoliisi Marko Forss kutsui nettivitsien tuntijat ymmärtämään kuvan ja siihen sisältyvän vitsin. Samalla osa hänen seuraajistaan jäi tämän joukon ulkopuolelle eikä ymmärtänyt viittausta. Verkkokulttuureissa joukkoon kuuluminen on keskeistä, ja usein ihmisiä yhteen sitovana aineksena toimii verkon kansanperinne. Kuvat ovat yhä keskeisemmässä osassa verkkosisältöjä niin nykyaikaisessa sotapropagandassa (Molin Friis 2015; Rodley 2016; Wiggins 2016) kuin huumorisivustoillakin. Verkko on yhä enemmän visuaalinen media (Paasonen 2011, 177). Meemit tarjoavat kiinnostavan kohteen digitaalisen visuaalisen kulttuurin tutkimukselle.

Limor Shifmanin mukaan meemien kolme ominaisuutta ovat asteittainen monistuminen yksilöltä yhteiskuntaan, kopioinnin ja matkimisen kautta tapahtuma jäljentäminen sekä kilpailun ja valinnan kautta tapahtuva levittäminen (Shifman 2014, 18). Matkiminen ja remixien tekeminen ovat tyypillistä meemien syntyprosessissa (ibid, 21-22). Meemit voidaankin ymmärtää myös osana remix-kulttuuria (Lessig 2008; Lankshear \& Knobel 2008), jolle on ominaista erilaisten kulttuurituotteiden muokkaaminen ja luova yhdisteleminen. Limor Shifmanin $(2014,86)$ mukaan meemeissä tyypillisesti esiintyviä piirteitä ovat tavalliset ihmiset, epäkelpo maskuliinisuus, huumori, yksinkertaisuus, toisto ja leikillinen sisältö. Näihin meemien piirteisiin tai ominaisuuksiin voidaan lisätä myös tunteiden ilmaiseminen, nurinkääntäminen (karnevalisointi), yllätyksellisyys ja "internetin ruman estetiikka" (Internet Ugly Aesthetics). Listaan voidaan liittää myös merkitysten sekoittaminen - propagandameemien kyseessä ollessa myös suoranainen merkitysten vääristely. Meemit voidaan ymmärtää myös outsider-taiteeseen verrattavissa olevana kansantaiteena (vrt. Haveri 2015).

Usein meemitutkimuksissa korostetaan meemien asemaa kulttuurisena tai poliittisena vastarintana (Burroughs 2013; Milner 2013; Esteves 2014; Mina 2014). Näin siksi, että kulttuurisen tai poliittisen vastarinnan kautta voidaan tuoda esiin meemien kantaaottavuus ja mahdollinen poliittinen vaikuttaminen. Meemimäinen sisältö on viraalista - virusmaisesti ja helposti leviävää -, ja siksi sitä on alettu käyttää myös propagandatarkoituksiin (Wiggins \& Bowers 2016; Rodley 2016). Esimerkiksi Chris Rodley (2016) kirjoittaa siitä, miten viraalisesti leviävää verkkopropagandaa käytettiin yleisen mielipiteen muokkaamiseen Israelin ja Gazan konfliktissa vuonna 2014. Meemimäisyyttä hyödyntävissä kiertävissä verkkosisällöissä pyrittiin esimerkiksi väitettyjen 
tai todellisten sodan uhrien kuvia käyttämällä vaikuttamaan ihmisten mielipiteisiin vastapuolesta. Samoin vastapuolen edustajat pyrkivät paljastamaan näitä kuvahuijauksia.

Meemejä onkin mahdollista käyttää nykyisen informaatiosodan välineinä ja esimerkiksi vihapuheen ja ennakkoluulojen levittämiseen. Esimerkiksi Karina Horsti (2016) on osoittanut, miten viraalisesti kiertävien kuvien avulla voidaan levittää islamofobista ideologiaa. Stereotyyppistä ylipainoista amerikkalaista esittävä Le American Bear -meemi puolestaan kaapattiin amerikkalaisille uusnatsisivustoille antisemitistisiin sarjakuviin, joissa karhu esiintyy hyväntahtoisena hölmönä ja joutuu kieron juutalaisen huijaamaksi (Bernstein 2015). Viruksen lailla kiertävät meemit (Jenkins \& al. 2013, 18) voivat siis levitessään välittää myös sellaista ideologista ainesta, jota meemin kierrättäjät alun perin eivät tietoisesti tarkoittaneet välittää.

Verkkokulttuurin kehyksessä meemejä ovat tutkineet esimerkiksi Victoria Esteves (2014), Limor Shifman (2014) sekä Olivia Rose Marcus ja Merrill Singer (2016). Meemejä on tarkasteltu myös visuaalisen kulttuurin näkökulmasta (Davison 2014; Brideau \& Berrett 2014; Douglas 2014). Harvinaisempaa niiden tutkiminen on yleisötutkimuksen (Miltner 2014), sukupuolen (Gal \& al. 2015) tai rodullisuuden (Horsti 2016; Nakamura 2014) näkökulmista.

Suomessa meemitutkimus on toistaiseksi varsin vähäistä, mutta esimerkiksi folkloristiikassa on virinnyt kiinnostus meemeihin (Heimo 2013). Pauliina Latvala (2015) on kirjoittanut poliittisista vitseistä ja verkkomeemeistä, Matti Kamppinen (2002) taas meemeistä uskonnossa. Mediatutkimuksessa Veikko Eranti (2014, 111-112) on Pekka Haaviston presidentinvaalikampanjaa käsittelevässä tutkimuksessaan sivunnut meemimäistä sisältöä poliittisen kampanjoinnin muotona, ja Journalismikritiikin vuosikirjassa Turo Uskali (2013) pohdiskelee Obama-meemien merkitystä Yhdysvaltain presidentinvaaleissa. Tämä artikkeli asettuu alakulttuurisen meemitutkimuksen perinteeseen (Shifman 2014; Esteves 2014; Milner 2013), sillä käsitellyillä meemeillä ei ole ilmiselvää poliittista agendaa. Ne asettuvat pikemminkin populaarikulttuurin ja nuorten nettihuumorin alueelle.

Kuvat ja meemit ovat erityisen keskeinen osa viestintää esimerkiksi verkon alakulttuureihin liittyvien kuvalautojen kulttuurissa. Kuvalauta on japanilaisten animesarjakuvien harrastajien yhteisönä alun perin toiminut keskustelufoorumi, jossa kommunikointi perustuu pitkälti kuvilla viestimiseen. Monet meemit saavat alkunsa kuvalaudoilta. Kuvalaudoilla viestien yhteyteen liitetään tavallisesti jokin kuva - joko satunnaisesti tai aiheeseen liittyen. Tätä kautta kuvalaudat toimivat keskeisenä meemien ja muiden ikonisten kuvien kierrättäjinä. (Suominen \& al. 2013, 138.)

Vilauta on suomalainen vuonna 2011 perustettu anonyyminä käytettävä kuvalauta (ks. myös Haasio 2015; Uotila 2013) - "Suomen 4chan"3. Se liittyy vahvasti anime- ja nörttikulttuuriin. Lisäksi se liittyy "A-kulttuuriin" eli anonyymiin verkkokulttuuriin, jolle on tyypillistä sosiaalisen median suosituimmuuskulttuurin vastustaminen. A-kulttuuri tarjoaa tilan identiteeteillä leikittelylle ja kiinnittymisen sisäpiirin vitseihin ja kulttuurisiin viittauksiin (Auerbach 2013). Milauta-foorumilla vierailee viikossa keskimäärin reilut 200000 uniikkia kävijää.

Tässä artikkelissa analysoin Yilauta-kuvafoorumilla esiintyneitä suomalaisia meemikuvia ja niihin liittyviä suomalaiseen kulttuuripiiriin liittyviä sisältöjä transnationaalin verkkokulttuurin kehyksessä4. Tarkemman analyysini kohteena on kaksi meemiä: Sad Frog ja Liekkipipo ja pirikiikarit. Nuorten suosimilla kuvalaudoilla ajatusmaailmaan kuuluu, että kaikelle saa nauraa.
3 Mediatutkija Limor Shifman $(2014,178)$ määrittelee 4chan-foorumin seuraavasti: "Kuvalautasivusto, jonne käyttäjät lataavat kuvia ja keskustelevat niistä. Foorumi on jaettu useisiin kanaviin, tai lautoihin, joissa on sisältöä määrätystä aihepiiristä ja omat sääntönsä. Suosituin lauta satunnainen, joka tunnetaan myös nimellä /b, on tunnettu villistä, aggressiivisesta ja usein tylystä puhetyylistä ja sisällöstä. Meemit ovat tärkeä osa 4chania, ja ne ovat keskeisessä roolissa monissa keskusteluissa. 4chan on myös hakkeriryhmä Anonymousin tärkeä keskuspaikka."

4 Artikkelissa käyttämäni aineisto on kerätty 23.5.2014 Ylilaudan "Ihmissuhteet"keskustelualueelta. Olen tallentanut kaiken kaikkiaan 300 keskusteluketjua pdf:nä ja Firefoxin Zotero-lisäosan avulla. Näistä keskusteluista olen poiminut sellaiset meemikuvat, joissa voidaan ajatella olevan suomalaista sisältöä (esimerkiksi kuvassa suomalainen julkisuuden henkilö tai populaarikulttuurin hahmo, meemin teksti on suomenkielinen, meemissä esiintyy suomalainen tuote tai meemi on kokonaisuutena ymmärrettävissä suomalaisen kulttuurin piiriin kuuluvaksi). Suomalaisten meemien määrittely on vaikeaa ja jossain määrin keinotekoista, koska meemien luonteeseen liittyy niiden globaali kierto eri kulttuuripiirien välillä, kuten myöhemmin tässä artikkelissa pyrin osoittamaan. 
Laura Hokkanen $(2015,370)$ onkin todennut mustan ja alatyylisen huumorin liittyvän usein lasten ja nuorten kiertävään kansanperinteeseen. Milauta on keskeinen verkkotila, jossa tätä nuorten alatyylistä ja mustaa huumoria sekä luodaan että välitetään eteenpäin.

Yilaudalla esiintyvissä suomalaisissa meemeissä ja tunnetiloja esittävissä reaktiokuvissa suosittuja aiheita ovat esimerkiksi muumihahmot, muut piirretyt hahmot - Nalle Puh ja Aku Ankka -, suomalaiset mieskoomikot - Spede Pasanen, Heikki Silvennoinen ja Aake Kalliala, jotka usein ilmentävät epäkelpoa maskuliinisuutta (ks. myös Halmetoja 2015) - ja iltapäivälehtien lööpeistä muokatut "Vanhanen vain nauroi"-tyyppiset meemit, joissa esiintyy usein suomalaisia poliitikkoja ja muita julkkiksia. Omistan artikkelin loppuosan kahden Milaudalla usein esiintyvän meemin tarkemmalle analyysille.

Artikkelissa analysoitavat meemit valikoituivat analyysini kohteiksi meemien runsaasta joukosta yleisyytensä, monistettavuutensa ja ilmaisuvoimansa takia. Eräs valintaan vaikuttanut syy olivat myös niiden versioissa esiintyvät suomalaiset elementit, joiden kautta voidaan pohtia meemien globaalia kiertoa: asettumista erilaisiin kulttuuripiireihin sekä globaaleihin, transnationaaleihin yhteyksiin.

\section{Transnationaali verkkokulttuuri}

Antropologit ovat tutkineet meemejä, anonyymiä verkkokulttuuria ja erilaisia verkosta nousevia ilmiöitä (Coleman 2014, Manivannan 2013, Auerbach 2012), mutta toistaiseksi tutkimusala on pitkälti Yhdysvalta-keskeinen. Verkkokulttuurin ilmiöiden problematiikka monimutkaistuu entisestään, kun siihen otetaan mukaan kysymykset rodullisuudesta/etnisyydestä, kansallisuudesta ja kulttuurieroista (esim. Horsti 2016; Chen 2014; Nakamura 2014; Sharma 2013).

Anonyymin verkkokulttuurin kollektiivinen muisti rakentuu sisäpiirin vitseille ja jaetuille viittauksille, ja tämä kulttuuri kukoistaa erityisesti verkon kuvalaudoilla, kuten suomalaisella Milaudalla. Myös saksalaiset, chileläiset ja brasilialaiset anonyymit ovat rakentaneet omat espanjan- ja portugalinkieliset kuvalautansa. Tässä mielessä Ylilauta ei ole ainutlaatuisen suomalainen verkkotila; se on suomenkielinen mutta meille muualta omaksuttu formaatti.

Verkkokulttuurissa on samalla sekä valtioiden ja kielten rajat ylittäviä piirteitä ja ominaisuuksia että rajatumpiin alueisiin liittyvää sisältöä, minkä vuoksi transnationalismin käsite on hyödyllinen verkossa kiertäviä ilmiöitä analysoitaessa. Kulttuurinen sisältö leviää transnationaalisti juuri verkossa (Fernback 2003; Jenkins ym. 2013). Transnationalismilla tarkoitetaan kansallisvaltioiden rajat ylittäviä ja maailmanlaajuisia taloudellisia, sosiaalisia ja poliittisia kytköksiä ihmisten, paikkojen ja instituutioiden välillä (Vertovec 2009, 1). Transnationalismi liittyykin olennaisesti globalisaatioon. Käsitettä voidaan käyttää myös tutkimuksellisena lähestymistapana, kun tarkastellaan kansallisen kansainvälisiä ulottuvuuksia tai kansallisen ja kansainvälisen vuorovaikutusta (Kääpä \& Seppälä 2012a; Kääpä \& Seppälä 2012b).

Transnationalismi-käsitteellä voidaan viitata hyvin erilaisiin verkostoihin ja yhteyksiin, kuten vaikkapa muuttoliikkeisiin tai elokuvien ja muiden kulttuurituotteiden globaaliin kiertoon. Katja Valaskiven ja Johanna Sumialan mukaan kierron käsite tarjoaa hyvän työkalun kulttuuristen ja sosiaalisten merkitysten teoreettiseen ja empiiriseen analyysiin (Valaskivi \& Sumiala 2014, 239). Valaskiven ja Sumialan mukaan sosiaaliseen mielikuvitukseen liittyvät merkitykset ovat kiinnittyneitä materiaalisiin esineisiin ja representaatioihin. 
Nämä merkitykset kulkevat moninaisia reittejä paikasta toiseen tuottaen uusia kohtaamisia ja assosiaatioita (ibid. 240), joten tekstit, kuvat, niiden katsojat ja kontekstit ovat kaikki jatkuvassa globaalissa liikkeessä. Kuvien ja kulttuurituotteiden globaali kierto on kiihtynyt verkon aikakaudella. Kiertävät mediatapahtumat vaikuttavat toisiinsa, ja kuten Arjun Appadurai $(1996,4-7)$ on todennut, mediakuvastoa voidaan omaksua nopeasti osaksi paikallista ironiaa, vihaa, huumoria ja vastarintaa.

Antropologi Arjun Appadurain (1996) mukaan tuotamme globaalissa maailmassa erilaisia paikallisuuksia ja paikallisen vastarinnan muotoja, ja myös uusilla globaaleilla median muodoilla on oma vaikutuksensa niiden tuottamiseen. Appadurai käyttää esimerkkinä paikallisista vastarinnan muodoista t-paitoja, graffitimaalauksia ja rap-musiikkia. Myös meemikuvat ovat osuva esimerkki ajatusten globaalista kierrosta ja omaksumisesta osaksi erilaisia ironian ja sosiaalisen kommentoinnin muotoja. Meemien toimintalogiikka on transnationaalisti jaettu, mutta toisaalta meemit ovat hyvinkin konteksti-sidonnaisia - varsinkin silloin, kun niihin liittyy jokin poliittinen agenda (ks. esim. Rodley 2016; Wiggins 2016). Joissain tapauksissa meemien on mahdollista olla samanaikaisesti sekä globaaleja että paikallisia, tai niissä voi olla samanaikaisesti sekä erittäin paikallisia elementtejä että globaalisti ymmärrettäviä viittauksia. Meemit ovat siis toisinaan "glokaaleja" eli samanaikaisesti sekä globaaleja että paikallisia.

Erilaiset meemihuumorin lajit ylittävät kulttuurien rajoja. Tällaisia ovat esimerkiksi rage-sarjakuviksi kutsutut yksikertaisesti piirretyt tunnetiloja esittävät tikku-ukkohahmot, jotka ovat levinneet maailmanlaajuisesti. Vaikka kiinalaiset rage-sarjakuvat ovat merkityksiltään ja kerronnan muodoiltaan erilaisia kuin amerikkalaiset (Chen 2014, 691), molemmat ovat kuitenkin tunnistettavasti estetiikaltaan rage-sarjakuvia. Siinä missä amerikkalaisissa rage-sarjakuvissa keskitytään useimmiten noloihin tai raivostuttaviin arkielämän kokemuksiin, kuvaavat niiden kiinalaiset vastineet laajempaa asioiden kirjoa ja kommentoivat myös yhteiskunnallisia epäkohtia (ks. Chen 2014). Rage-sarjakuvat ja muut meemit ovat irronneet verkon aktiivikäyttäjien, kuten Reddit ja 4chan -foorumien aktiivien, hallusta myös muille alustoille ja valtajulkisuuteen asti. Rage-sarjakuvista on useita kulttuurisia tulkintoja, jotka voivat erota niiden alkuperäisistä "oikeista tulkinnoista", joita alkuperäisen verkkokulttuurin piirissä olevilla aktiivikäyttäjillä on.

Sen lisäksi, että internetin meemikuvat kutsuvat itseään uudelleen käytettäviksi, monistettaviksi ja levitettäväksi, ne ovat myös intermediaalisia (ks. Lehtonen 1999) - ne sisältävät mediarajat ja -genret ylittävää verkkokulttuurista peräisin olevaa tekstien ja mediumien välistä merkitysten liikettä. Kulttuuriset resurssimme eivät ole koskaan peräisin vain yhdestä mediumista (ks. Lehtonen 1999, 11) vaan tuomme mediatekstien tulkintatilanteeseen mukaan myös muita omaksuttuja merkityksiä. Meemien intermediaalisuus on joskus viety niin pitkälle, että niissä esiintyvät hahmot irtoavat aikaisemmasta merkityksestään ja alkavat symboloida verkon alakulttuurissa jotain aivan muuta. Näin kävi esimerkiksi artikkelin alkupuolella esiin tulleelle Spurdo Spärdelle, joka sai alkunsa Pedobear-meemistä mutta monistui ja kehittyi esittämään esimerkiksi karikatyyristä poliisia ja alikersanttihahmoa.

Aiempien merkitysten lisäksi meemeihin tarttuu niiden kiertäessä myös uusia merkityksiä. Usein meemikuvat sisältävät omituisia ja yllättäviä rinnastuksia. Useimmiten ne viittaavat toisiin meemeihin, eikä niiden tarkoitus olekaan avautua kulttuurin ulkopuolisille. Päinvastoin uusien kulttuuristen merkitysten tuottamisessa on kyse eronteosta, rajanvedoista ja oman kulttuu- 
rin ja yhteisön rajojen vartioinnista - eräänlaisesta elitismistä, joka perustuu kulttuuriin kuulumiseen (Douglas 2014; Manivannan 2013; Auerbach 2013). Väitänkin, että meemejä ei ole järkevää analysoida ottamatta huomioon sitä verkkokulttuuria ja verkkotilaa, jossa meemi esiintyy.

\section{Tunteiden ilmaiseminen meemien kautta - tapaus Sad Frog}

Sad Frog tai "Pepe the Frog" on suosittu meemi, piirroskuva surullisen näköisestä sammakosta, jolla kuvitetaan pettymyksen tai epäonnistumisen tunteita tai surullisuutta joko käyttäen kuvaa tai siihen liittyvää tekstiä "feelsbadman.jpg". Sad Frog on kehittynyt sarjakuvapiirtäjä Matt Furien piirtämästä Pepe-sammakosta, josta syntyi ensimmäinen sammakkomeemi "Feels Good Man"5 (Kuvassa 1, ylhäällä vasemmalla).

Pepe-sammakko tai Sad Frog on synnyttänyt oman fanijoukkonsa, ja versioita sammakkomeemistä tehdään jatkuvasti lisää. Sammakosta, kuten monista muistakin meemeistä, on tullut suosittu myös lasten keskuudessa. Pepe-sammakko puhuttelee, koska se on niin ilmaisuvoimainen ja muuntautumiskykyinen. Se pystyy edustamaan monenlaisia tunteita ja kokemuksia. Siinä mielessä sammakko on kuten hymiöt tai emoticonit: helppo tapa kehystää viesti tunteella. Itse asiassa tunteiden kuvittamiseen tarkoitetut hymiötkään eivät ole yksiselitteisiä, vaan eri ihmiset tulkitsevat hymiöiden ilmeitä osittain eri tavoin (ks. Miller et al. 2016). Suomalaisen Sad Frog -meemin merkityspotentiaali ei kenties ole täysin sama kuin amerikkalaisella Sad Frog -meemillä, vaan suomalainen surullinen sammakkomeemi kytkeytyy tiiviisti juuri niihin keskusteluihin, joiden osana sitä useimmiten käytetään ja joiden pohjalta sen ilmaisuvoima ja siihen liittyvät merkitykset rakentuvat.

Sad Frog -meemiä voidaan kutsua "tahmaiseksi" eli sellaiseksi sisällöksi, joka helposti herättää ihmisten mielenkiinnon ja halun osallistua ja johon erilaisten liikkuvien ja leviävien merkitysten kiinnittäminen on helppoa. Meemit ovatkin sekä tahmaisia että levitettäviä (Jenkins \& al. 2013, 4). Sad Frog -meemi on erityisen tahmainen, minkä todistaa sen levinneisyys ja suosio. Sammakon tahmaisuus liittynee siihen, että siihen on helppo kiinnittää erilaisia tunteita. Tunteet liittyvät tahmaisuuteen siten, että jotkin kuvat tai asiat ovat "tahmaisempia" kuin toiset, jolloin tunteet kiinnittyvät niihin erityisen hyvin (Ahmed 2004, 4, 8; Paasonen 2014, 179-190). Siinä missä yksinkertainen hymiö kuvaa jotakin tunnetta yleisellä tasolla, voidaan kasvonilmeitä esittävillä meemikuvilla ilmaista tunteita laajemmalla skaalalla, kuten esimerkiksi suosituissa "Ilmeeni kun" -meemeissä ("My Face When...").

Ehdotan, että meemejä tulkittaessa olisi kiinnitettävä huomiota ainakin viiteen seikkaan: meemin konteksti, tunnerekisteri, muoto, tavoitteet ja rakennusaineet. Tulkitkaamme siis perusmuotoista Sad Frog -meemiä (kuvassa 1, ylimmän rivin keskimmäinen kuva) näiden viiden tekijän avulla. Ensinnäkin tässä tapauksessa meemin konteksti on ollut Milaudan ihmissuhteita käsittelevissä keskusteluissa, joissa esimerkiksi kysytään seurustelusuhteisiin liittyviä neuvoja. Meemin tunnerekisteri on tässä tapauksessa varsin selvä: se ilmentää esimerkiksi surua, pettymystä ja mielipahaa. Meemin tavoitteena on surullisen tunnetilan ilmaisu, ja sen rakennusaineena on Matt Furien piirtämä Pepe the Frog -sarjakuvahahmo.

Sad Frog -meemien kollaasi (kuva 1) tuo hyvin esiin meemien tavallisimpia piirteitä ja kuvaa myös visuaalisten viestien muokkautuvuutta meemin kierrossa. Kollaasiin kerätyissä meemikuvissa esiintyy vaihtelevia tunteita,
5 Ks. meemitietokanta "Know your meme", <http://knowyourmeme.com/memes/feels-badman-sad-frog>. 

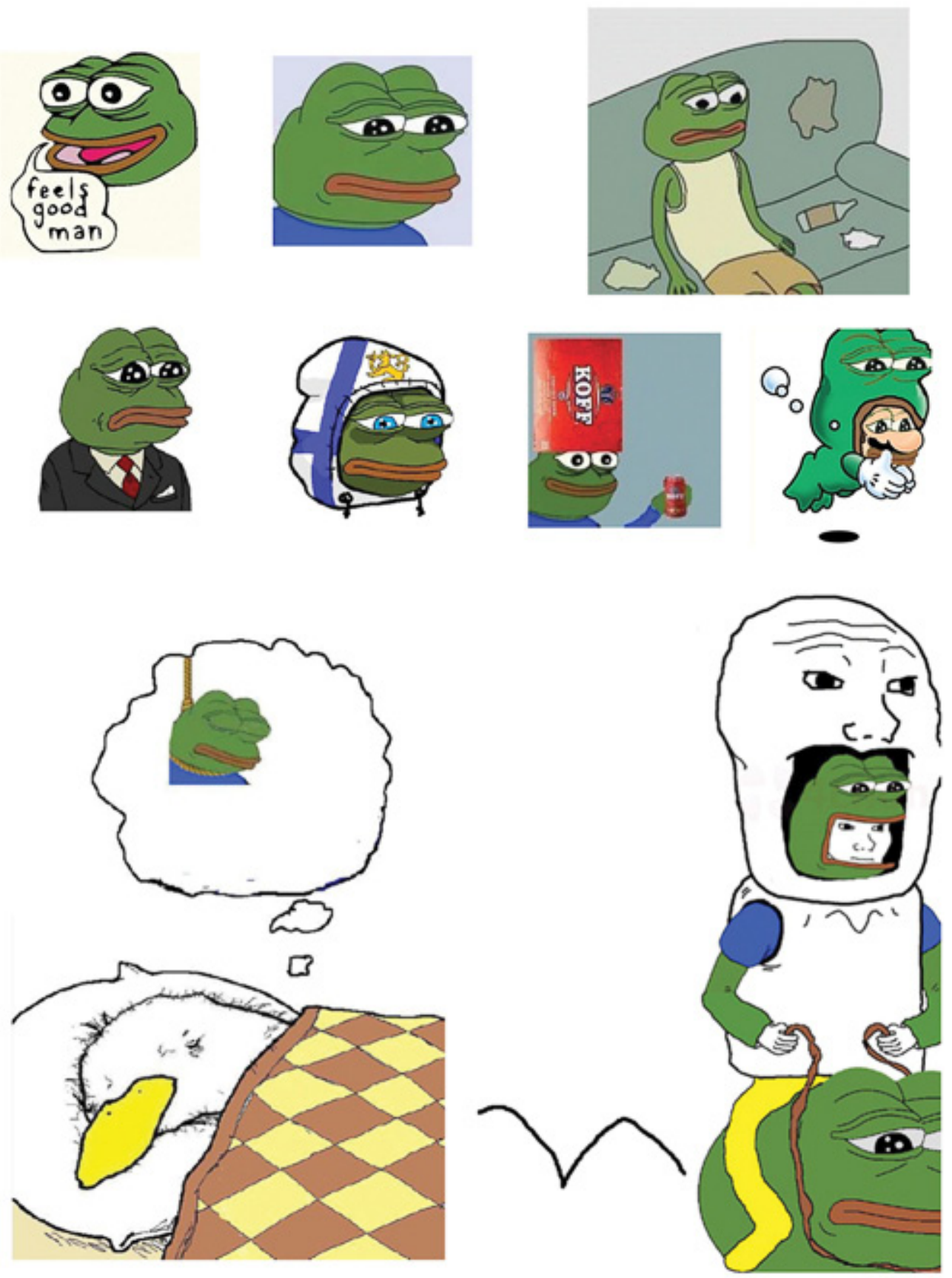

Kuva 1. Kollaasi muutamista Sad Frog -meemin variaatioista Ylilauta-foorumin "Ihmissuhteet"-alueelta 23.5.2014. Kollaasin tehnyt: Eliisa Vainikka.

kuten surullisuus, ilo, pettymys ja vihaisuus. Meemin tunnerekisteri on pääasiallisesti kuitenkin negatiivinen. Sad Frog -kuvissa on esimerkiksi viittauksia itsetuhoisuuteen (hirttäytynyt sammakko), alkoholiin (sohvalla olutta juova sammakko ja Koff-sammakko) ja populaarikulttuuriin (viittaus Super Mario -hahmoon). Milaudan "Hikikomero"-keskustelualuetta tutkineen Ari Haasion (2015, 111-114; Haasio \& Zechner 2014, 51-52) mukaan palstalla keskustelevat kokevat itsensä "toisiksi" suhteessa valtaväestöön tai "normaaleihin" nuoriin. Tätä toiseuden kokemusta voidaan kuvittaa meemeillä, kuten kuvan 1 kollaasissa olevat surulliset tai itsemurhaa yrittävät sammakot. Kuten 
Shifman toteaa, meemit ovat keskeinen linkki henkilökohtaisen ja poliittisen välillä (Shifman 2014, 129).

Muutamassa sammakkokuvassa tulee esiin myös erityisesti suomalaisia asioita; eräällä sammakolla on päässään Suomen lipulla ja Suomen leijonalla kuvitettu päähine, toisella taas Koff-oluen laatikko ja räpylässään oluttölkki. Sammakkomeemistä on myös olemassa versio, jossa sammakko on pukeutunut Jussi-paitaan. Meemin tunteva amerikkalainen voi ymmärtää kuvan olevan Sad Frog -variaatio, mutta Jussi-paitaan liittyvät konnotaatiot eivät avaudu amerikkalaiselle. Tämä on hyvä esimerkki siitä, millä tavoin meemit voivat olla samanaikaisesti sekä paikallisia että transnationaaleja - siis glokaaleja. Tässäkin on kyse meemin esiintymiskontekstista. "Suomalaisuuden" esittämisellä lienee meemien tekijöille oma merkityksensä.

Pohdin artikkelin lopussa lyhyesti sitä, millä tavoin suomalaisia meemejä "viedään" maailmalle. Sad Frog -meemeissä viittaukset suomalaisuuteen on kuitenkin tarkoitettu enemmänkin tuottamaan suomalaisten keskinäistä yhteenkuuluvuutta kuin olevan "meemivientiä" kansainvälisille kuvalaudoille. Ne voidaan tulkita suomalaisten sisäpiirin vitseiksi.

Sad Frog -meemin kautta ilmaistaan tai toistetaan suomalaisissa Ylilautakeskusteluissa useimmiten surullisuuden kirjoa. Meemi perustuu itse asiassa alun perin nurinkääntämiseen, koska sen edeltää on hyvää tunnetta välittänyt Pepe-sammakkohahmo "Feels Good Man" (kuvassa 1, vasemmalla ylhäällä). Meemin muodolla tarkoitan oikeastaan sen mediumia: meemit voivat olla valokuvia, kollaaseja, videoita tai esimerkiksi kuvamuokkauksia. Sad Frog -meemi perustuu sarjakuvahahmolle, joten sen muoto on sarjakuvahahmon perusteella muokattu piirros. Kuten kuvasta yksi huomataan, meemin variaatiot voivat olla myös rumasti piirrettyjä versioita, jotka kuvastavat erinomaisesti Douglasin (2014) esittelemää internetin ruman estetiikkaa.

Sad Frog on myös ruokkinut luovuutta niin, että siitä on tehty variaatioita, joissa se on remixattu muihin meemikuviin. Yksi esimerkki tästä on "I Know That Feel Bro" -meemi (kuvassa 1, oikealla alhaalla). Intertekstuaalisuus eli eri tekstien väliset viittaukset ovat meemeille tyypillisiä. Eräässä Sad Frog -meemin muunnelmassa sammakkohahmo on asetettu Breaking Bad -televisiosarjan tunnuskuvaan, joka on otsikoitu uudelleen sanoilla "Feeling Bad". Pepe-sammakon Facebook-faniryhmässä taas esiintyy enemmän kuvamuokkauksia, joissa sammakko liikkuu erilaisissa tilanteissa sen sijaan, että vain ilmaisisi yhtä tunnetta eli surullisuutta.

Siinä missä kiinalaiset aktivistimeemit (Mina 2014) ovat poliittista vastarintaa virallista propagandakoneistoa vastaan, voivat anonyymit verkkokulttuurin meemit ainakin joissain tapauksissa edustaa leikin kautta toteutettua vastarintaa sosiaalisen median minä-brändäämistä ja itsensä markkinointia vastaan. Siinä missä sosiaalisen median palveluissa sosiaaliset piirimme ja identiteettimme osat latistetaan yhteen (Cirucci 2015; boyd 2008, 293), tarjoavat anonyymit foorumit tilan, jossa käsitellä näiden sosiaalisen median palveluiden ulkopuolelle jääviä asioita. Tällaisia ovat esimerkiksi negatiiviset tunteet ja henkilökohtaiset ongelmat (vrt. Haasio 2015), joita ei ole mahdollista tuoda esiin muissa verkostoissa. Meemihuumoria voidaan ajatella myös vakavia aiheita keventämään pyrkivänä "parantavana" huumorina, vaikka esimerkiksi Milaudan huumori onkin usein luonteeltaan negatiivista. 


\section{Merkitysten sekoitus - Liekkipipo ja pirikiikarit}

Kuvan 2 meemissä Nalle Puh -hahmo esiintyy lähikaupasta olutta hakevana äijänä. Tunnistamme kuvan sijoittuvan Suomeen, koska hahmon taustalla on Siwa-lähikauppa ja suomalaisen postin tunnukset. Lastenkirjoista ja -elokuvista tuttu sympaattinen ja hyväntahtoinen hahmo on heitetty harmaaseen ja arkiseen maisemaan, otokseen jokapäiväisestä elämästä. Kuvassa Nalle Puh kävelee tyytyväisen näköisenä Siwasta päässään liekkipipo ja kainalossaan laatikko (24-pack) Karhu-olutta. Oikeassa tassussaan Nalle kantaa puukkoa.

Meemitietokanta Urbaanisanakirjan mukaan liekkikuvioitu pipo "mielletään osaksi päihteiden väärinkäyttäjien, pitkäaikaistyöttömien, pikkurikollisten ja niin sanottujen elämänkouluun kuuluvien henkilöiden vakioasustusta. Käytetään yleensä pirikiikari-mallisten aurinkolasien kera". (Urbaanisanakirja 2014.) Nuorten suomalaisten netinkäyttäjien on helppo tulkita tämä kuva, mutta ihmisille, jotka eivät elä urbaanissa suomalaisessa (nuoriso)kulttuurissa, kuva ei avaudu helposti. Siksi pirikiikarien merkitystä on esimerkiksi kyselty vauva.fi-keskustelupalstalla. ${ }^{6}$ Osa meemeistä on kulttuurisidonnaisia, eivätkä ne siten avaudu kyseisen kulttuurin ulkopuolisille. Usein meemien syntyhistoriat ovat monimutkaisia, ja joskus niitä on vaikea jäljittää. Kuten kiertävistä kansanperinteen tarinoista, myös nettimeemeistä liikkuu erilaisia versioita. Esimerkiksi Liekkipipo ja pirikiikarit -meemi tunnetaan myös nimellä Vauhtilasit ja vauhtipipo (Lepistö 2016).

Kuvan 2 meemissä Nalle Puh edustaa alempaa sosiaaliluokkaa, minkä voi päätellä asusteista (liekkipipo, tummat aurinkolasit). Myös kaljakeissin voidaan lukea symboloivan tietynlaiseen kuluttajaryhmään kuulumista - yhdessä asusteiden kanssa kaljan suurkuluttajuutta. Liekkipipopäinen kaveri onkin

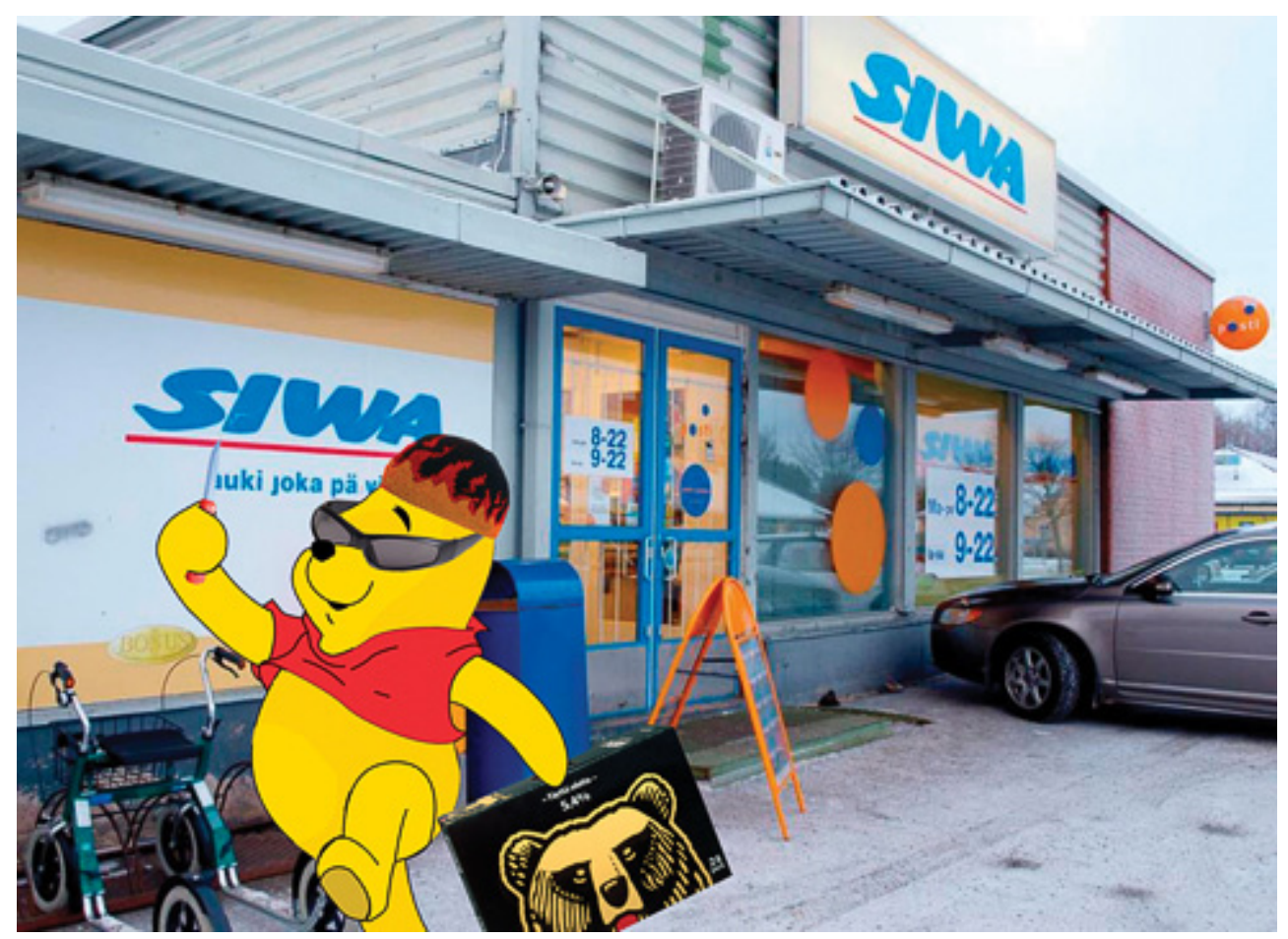

Kuva 2. Liekkipipo ja pirikiikarit -meemin variaatio. Kuva: Ylilauta.
6 Keskustelu vauva.fi-keskustelupalstalla "Voisko joku selittää?" <http://www.vauva. fi/keskustelu/4437886/ketju/ voisko_joku_selittaa> (linkki tarkistettu 21.9.2015). 
tyytyväinen ryöstettyään kaupasta niin sanotut juoksukaljansa. Varastettu olut liittyy usein Liekkipipo ja pirikiikarit -meemiin. Liekkipipo-meemin muoto on kuvamuokkaus tai remix. Sen rakennusaineet tulevat meemeille tyypillisesti monesta eri lähteestä: Valokuva Suomesta ja Nalle Puh -hahmo Disneyltä. Meemiin erityisesti kuuluvat suomalaiset asusteet taas on lisätty kuvan hahmolle myöhemmin.

Viattomien kulttuuristen symbolien käyttö ja nurinkääntäminen uusiin merkityksiin ovat meemeille tyypillistä. Karnevalistisessa huumorissa kumotaan hierarkkisia suhteita ja käännetään asioita nurin (Bahtin 1995 [1965], 11-12). Monen meemin vitsi piileekin viattoman kääntämisessä rumaksi. Meemikuvissa populaarikulttuurin hahmot saavat uusia muotoja, ja hahmojen merkityksiä muokataan yhdistämällä niitä muihin kulttuurisiin elementteihin - esimerkiksi niin, että Nalle Puh kiroilee tai Muumipeikko polttaa kannabisjointtia (ks. Lepistö 2016).

Keskiajan ja renessanssin karnevalistisessa kulttuurissa vakavat asiat käännettiin nurin ja niistä tehtiin naurunalaisia. Tämän nurinkääntämisen on nähty sekä horjuttaneen voimassaolevia valtasuhteita että vahvistaneen vallitsevia valtasuhteita; tämä siksi, että karnevaalien jälkeen palattiin aina voimassaolevaan yhteiskunnalliseen järjestykseen. (Bahtin 1995 [1965]; Kolehmainen 2015.) Karnevalismi kuitenkin tarjosi mahdollisuuden ilmaista tyytymättömyyttä tilanteessa, jossa se ei muutoin ollut mahdollista. Kuten Marjo Kolehmainen väitöskirjassaan toteaa: karnevalismi muistuttaa siitä, että parodian juuret ovat kansankulttuurissa (Kolehmainen 2015, 36).

Liekkipipo ja pirikiikarit -meemin asusteet (pipo ja aurinkolasit) on helppo liittää eri hahmoille, mikä tekee meemistä helposti monistettavan. Meemillä irvaillaan sekä söpön kääntämiselle rumaksi että yhteiskuntaluokalle - niin sanotulle elämänkoululaisuudelle, joka on internetin anonyymien palstojen slangissa muodostunut termiksi kouluttamattomuudelle, huumeiden käytölle ja muunlaiselle yhteiskunnan hyvän elämän normeista poikkeamiselle. Siinä missä Sad Frog -meemin itseironinen pilkka ja negatiivinen huumori tuntuvat usein osuvan kirjoittajaan itseensä, kohdistuu Liekkipipo-meemin pilkka usein "toisiin": elämänkoululaisiin. Liekkipipo-meemin hauskuus syntynee toiston ja yhdessä muistelun kautta (vrt. Rantala 2015, 91). Kun asusteet liitetään yhä uusille hahmoille, kuten muumien Haisulille, Tiuhdille ja Viuhdille (Lepistö 2016) tai juoksija Usain Boltille, tulee jutusta jaetun ymmärryksen kautta hauska, vaikkei aihe sinänsä olekaan humoristinen. Pilkallinen kansanperinnehuumori on kuitenkin tunnettua jo historiallisesti (Rantala 2015, 83), eikä pilkkaa voida pitää verkossa kiertävien vitsien erityisominaisuutena. Usein epäkorrekti huumori liittyy nimenomaan lasten ja nuorten pilantekoon (Hokkanen 2015, 370). Liekkipipo-meemin tavoitteena lieneekin tunnetun meemin versiointi ja nurinkääntämisen kautta tapahtuva vitsailu. Sen kontekstina puolestaan on verkkokeskustelupalsta Ylilauta.

Kuva 3 on sosiaalisessa mediassa levinneestä "hattumies" Antti Ritan 100 Days of Hats -blogista, jossa hän poseeraa joka päivä päässään erilainen hattu. Yksi kuvista on viittaus Liekkipipo ja pirikiikarit -meemiin. Meemien kautta voidaan pyrkiä tavoittelemaan symbolista valtaa, mutta tämä on vaikeaa meemien monitulkinnallisuuden ja dadaistisuuden takia. Meemit eivät myöskään varsinaisesti kuulu kenellekään. Niillä on oma merkityspotentiaalinsa, jolla rakennetaan omaa rinnakkaistodellisuutta ja symboliikkaa. Internetkulttuuria tuntemattomille liekkipipon ja pirikiikarien merkitys ei liene suuri, vaan meemin merkitys ja samalla myös huumori rakentuu nimenomaan jatkuvalle toistamiselle ja erilaisten variaatioiden tekemiselle samasta aiheesta. 


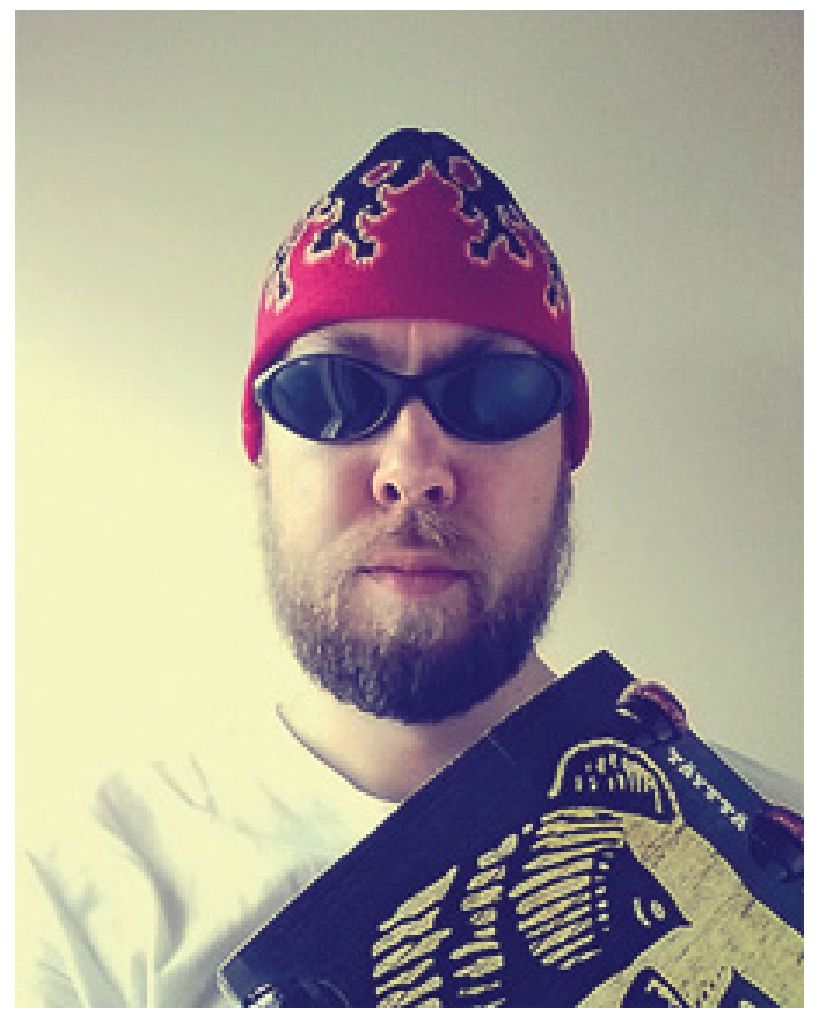

Kuva 3. "Hattumies" Antti Ritan tulkinta Liekkipiposta ja pirikiikareista osana 100 Days of Hats -projektia, jossa Rita poseeraa sadan päivän ajan joka päivä päässään eri hattu. (Kuva tekijän luvalla.)

Liekkipipo-meemi on verkon kansanperinnettä, ja esimerkiksi Antti Ritan hattuvideoon lainattuna se on tarkoitettu nimenomaan nettikulttuuria tunteville avautuvaksi viittaukseksi samaan tapaan kuin artikkelin alussa esittelemäni nettipoliisi Fobban Facebook-taustakuva. Meemi kuitenkin irtoaa myös alkuperäisestä merkityksestään, kun lapset ja nuoret katsovat YouTubesta löytyviä videoita pirikiikareita käyttävästä Haisulista. Meemiin viittaava "sairaan nopee" -toteamus leviää nuorten keskuudessa, ja äidit kyselevät vauva.fi-keskustelupalstalla, mitä "sairaan nopee" tarkoittaa. Meemin huumori syntyy yllättävistä yhdistelmistä, kuten siitä, että Nalle Puh nähdään päihteisiin sortuneena. Nalle Puhin kaltaisten hahmojen kunnollisuus ja hyväntahtoisuus käännetään meemissä vastakohtaiseksi niin, että hyvästä ja söpöstä tulee epämiellyttävä ja epäonnistunut. Meemien käytössä vastakohdiksi asettuvat usein virallinen ja absurdi, vakava ja leikkisä sekä menestys ja epäonnistuminen.

\section{Verkkotilan rakentaminen ja vartiointi pilailun kautta}

Tässä artikkelissa käsittelemäni meemit ironisoivat kansanomaista suomalaisuutta. Kansanomaisuutena voidaan ymmärtää myös niiden ruman estetiikka (Douglas 2014). Usein meemikuviin tehdyt piirretyt muokkaukset on toteutettu tarkoituksellisen kömpelösti "Paint-tyylillä" (Halmetoja 2015). Auerbachin mukaan anonyymien pilanteko ei ole kyllästynyttä hipsteri-ironiaa (Auerbach 2012) vaan ennemmin kansanomaista jokamiehen pilantekoa. Kansanomaisuutensa takia meemihuumori voidaankin liittää Bahtinin (1995 [1965]) analysoimaan keskiajan ja renessanssin kansannauruun. Ruman estetiikka asettuukin 
myös siloteltua sosiaalisen median minä-brändäyskulttuuria vastaan. Netin meemikuvat asettuvat siis kansantaiteen perinteeseen.

Meemit voivat ilmentää kulttuurisia identifikaatioita, tosin niissä samanaikaisesti sekä samastutaan että pilkataan niitä. Vielä enemmän kuin varsinaisesti suomalaisuudesta osa suomalaisista meemeistä kertoo myös yhteiskuntaluokasta. Meemeissä esiintyvät symbolit, kuten liekkipipot ja Pirkka-olut, kertovat elämäntavasta ja luokasta. Tämä luokan ja elämäntavan esittäminen onkin yksi keskeisistä anonyymin (vasta)kulttuurin ja näkyvyyteen tähtäävän julkisuuskulttuurin eroista.

Meemien kautta voidaan esittää omaa todellisuutta - erityisesti vastapainona mahdollisimman suureen näkyvyyteen ja minä-brändäämiseen tähtäävälle julkisuuskulttuurille, jota Twitterin ja Instagramin kaltaiset sosiaalisen median palvelut edustavat. Mikko Lehtosen mukaan performatiivisuus on keskeistä siinä, miten yhteisöt uusintavat itseään päivästä toiseen. Performatiivisuuden kautta tapahtuva toisto saa aikaan tunteen jatkuvuudesta ja yhdenmukaisuudesta. (Lehtonen 2004, 124.) Huumorin kriittinen terä (Hutcheon 1995) ei seuraa välttämättä odotettuja yhteiskunnallisia järjestyksiä. Milaudan meemien pila esimerkiksi kohdistuu vain silloin tällöin vallanpitäjiin ja useasti osattomiin toisiin.

Meemit käyttäjälähtöisenä sisällöntuotantona voidaan ymmärtää joissain tapauksissa myös osallistumisena yhteiskunnassa ja kielenkäytössä tapahtuvaan ideologiseen kamppailuun (Horsti 2016; Wiggins 2016; Rodley 2016). Shih-Wen Chen on kirjoittanut kiinalaisten rage-sarjakuvien (baozou manhua) toimivan tekijöilleen ja kuluttajilleen poliittisen ja emotionaalisen katharsiksen lähteenä (Chen 2014). Meemien tekeminen voi myös olla eräänlaista vastaanpuhumista, jossa tuotetaan näkemyksiä siitä, miten "meidät" ja "heidät" nähdään. Ari Haasio esimerkiksi toteaa Ylilauta-foorumia käsittelevässä väitöskirjassaan, että foorumilla keskustelevat kokevat arvokkaaksi ja omien arvojen ja arvostustensa kannalta mielekkääksi "erilaisena toisena" olemisen (Haasio 2015 , 78). Suomalaiset meemit voivat kenties tuottaa katharsis-kokemuksia, sillä niiden kautta on mahdollista esittää toiseuden kokemuksiaan sekä negatiivisia käsityksiä itsestä ja omasta elämästään (kuten Sad Frog -meemissä).

Olli Löytyn $(2004,102)$ mukaan riena on yksi, joskus vapauttavakin tapa kertoa historiaa uusiksi. Hän kirjoittaa: "Mistä sen tietää, vaikka koko kansakuntaisuuden idealle tekisi hyvää, jos kansallista vahakabinettia välillä tuuletettaisiin, suurmiehille tökättäisiin hassut nenät ja keskiaikaisten karnevaalien tapaan juhlittaisiin edes yhden päivän ajan 'vääriä kuninkaita' ja miksei yhtä hyvin vääriä kuningattariakin." (Löytty 2004, 102.) Verkossa tällaista vallanpitäjien karnevalisointia tapahtuu, tosin nettipila ei kohdistu vain vallanpitäjiin vaan osuu myös moniin muihin ryhmiin. Itse asiassa kukaan ei ole turvassa nettipilailun kohteeksi joutumiselta, ja erityisen herkästi trollaamisen kohteiksi joutuvat he, jotka eivät ymmärrä kyseistä kulttuuria tai ovat muuten hyväuskoisia hölmöjä (Coleman 2014, 31). Tässä mielessä nykypäivän verkkokulttuurissa on varsin julmia piirteitä (ks. esim. Whelan 2013).

Suomalaiset meemit sisältävät monesti oudoksi miellettyä huumoria. Tämä näkyy esimerkiksi suomalaisilta kuvalaudoilta alkunsa saaneen huonosti piirretyn Aku Ankka -kopion "Uncle Dolanin" suosiossa (Halmetoja 2015). Suomalaista nettikulttuuria tunnutaan myös jossain määrin vietävän - tai "pakotettavan" (Lepistö 2016) - kansainvälisille foorumeille, jotta erilaiset meemihahmot leviäisivät ulkomaille. Kerrotaan esimerkiksi, että Heikki Silvennoisen kasvokuvasta muodostunut "Tonnin seteli" -meemi tunnetaan saksalaisilla kuvalaudoilla nimellä "The King of Finland". Kuvanjakosivustolla 
suomalaiset käyttäjät tervehtivät toisiaan suomalaisen kuvan noustessa esiin todeten: "Suomi mainittu, torilla tavataan!" (Halmetoja 2015.)

Suomalaisuus meemeissä yhdistää kansallisesti, ja myös globaalissa verkossa kansallisten ja paikallisten symbolien merkitys on yhä läsnä. Suomalaisten keskinäistä yhteyttä rakennetaan esimerkiksi Suomi-meemejä huomioimalla aina, kun niitä tulee kansainvälisillä sivustoilla vastaan. Suomalaisten meemien leviäminen ja levittäminen kuvaavat osaltaan samanlaista mediayleisöjen muutosta, laajenemista ja hajaantumista, kuin mistä Anu Lahtinen kertoo artikkelissaan, joka käsittelee amerikkalaisen talk show -isäntä Conan O'Brienin ja tämän suomalaisten fanien välistä suhdetta (Lahtinen 2009, 36). Talvella 2005-2006 O’Brienin suomalaiset fanit lähettivät tälle aktiivisesti postia, ja O'Brien puolestaan nosti suomalaisia asioita ja fanejaan esiin ohjelmassaan. Suomalaiset meemit voidaan ymmärtää tavis-julkisuuden nousuna. Tämänkaltaisessa julkisuudessa haistatetaan pitkät eliittijulkisuudelle (Lehtonen 2004, 145) ja tuotetaan erilaisia suomalaisuuden symbolien kuvauksia banaaleista taviksista (Nikunen 2007) meemien kautta.

Meemien kierto ei kuitenkaan ole suoraan verrannollinen kantaaottavaan vastakulttuuriin (Appadurai 1996, 4-7), kuten punk- tai rap-musiikkiin. Meemikulttuuri sisältää liikaa monitulkintaisuutta, absurdeja ja dadaistisia elementtejä ja postmodernia ironiaa, joka toisaalta häivyttää vakavasti otettavia poliittisia viestejä, toisaalta voi myös piilottaa propagandatarkoituksessa lähetettyjen meemien viestiä. Kuten dadaismissa (Esteves 2014), myös meemien tarkoituksena on välillä hämmentää ja raivostuttaa suurta yleisöä. Ironialla on terä, joka kohdistuu aina johonkin. Samoin sillä on lähettäjä ja tulkitsija, joista ironian merkitys on riippuvainen (Hutcheon 1995). Esimerkiksi nuoret eivät ehkä halua aikuisten ymmärtävän heidän omia juttujaan. Monet nettimeemit pakenevat jaettuja merkityksiä: kun valtavirran suuri yleisö on saanut kiinni meemin merkityksestä, on se jo muuttunut lukemattomiin muihin muotoihin, ja sen tilalle on syntynyt uusia. Tässä mielessä Henry Jenkinsin ja kumppanien (2013) käyttämä virusmetafora on osuva.

Kuten Linda Hutcheon (1995) toteaa, ironia voi olla sekä radikaalin poliittista että konservatiivista, kuten esimerkiksi verkossa leviävät konservatiiviset äänet osoittavat. Hutcheonin mukaan ironia onkin transideologista. Se voi siis toimia monenlaisten ideologioiden puolesta. Tarkoitushakuiset poliittiset meemit käyttävät hyväkseen tätä monitulkintaisuuden mahdollisuutta ja erilaisten kuva-aineisten vapaata yhdistelemistä oman päämääränsä ajamiseksi (ks. esim. Vainikka 2016; Rodley 2016).

Meemimäinen propagandasisältö onkin viime vuosina noussut esiin eräänlaisena vakiintuneena esittämistapana erilaisissa verkkotiloissa. Kuvalautafoorumeilla asenne on usein liberaali ja välinpitämätön, pilanteko on sallittua kaikenlaisista aiheista ja loukkaavakin sisältö ja puhetapa kuuluvat verkkotilan kulttuuriin. Ironia kätkee sisäänsä asenteen tai tunteen (Hutcehon 1995), ja sen avulla voidaan tuomita muita tai tuottaa sisäpiirejä. Meemien avulla voidaankin vartioida verkkotilan rajoja ja pyrkiä pitämään tila vakiintuneiden käyttäjien omana. Esimerkiksi Vyshali Manivannan (2013) on osoittanut, miten loukkaavien ilmaisujen avulla 4chan-foorumilla pyritään karkottamaan ei-toivottuja käyttäjiä. Omituisella ja satunnaisella "dadaistisella" meemisisällöllä voidaan vartioida verkkotilan rajoja, tuottaa jaettujen kuvien ja tarinoiden kautta yhteisöllisyyttä ja samalla tuottaa kyseisen verkkotilan "ominaislaatuisuutta".

Milauta on hyvä esimerkki tällaisesta samalla paikallisesta mutta vahvasti globaaleja vaikutteita sisältävästä verkkotilasta. Se on suomenkielinen ja sitä 
kautta paikallinen foorumi, mutta kuvalautataustansa takia Milauta kytkeytyy vahvasti japanilaiseen anime-kulttuuriin samoin kuin amerikkalaiseen anonyymiin verkkokulttuuriinkin (4chan-foorumi). Koska foorumin nuoret suomalaiset käyttäjät ovat kielitaitoisia ja todennäköisesti liikkuvat myös muissa rinnakkaisissa verkkotiloissa (Reddit, 4chan), saadaan Milaudalle vaikutteita myös sitä kautta. Siksi Ylilautaa ei voida pitää täysin paikallisena (suomalaisena) verkkotilana vaan pikemminkin glokaalina. Paikallisuuden määrittäminen onkin verkkotilojen osalta vaikeaa siitä huolimatta, että suomen kieli rajaa meillä vahvasti käyttäjäpopulaatiota. Usein nettimeemeihin liittyy kuitenkin myös perustavanlaatuinen epäilys: niiden dadaistinen sisältö voi olla satunnaista ja jopa sellaista, josta ei voida tulkita sen kummempaa vitsiä tai ideologiaa.

\section{Johtopäätökset}

Tämä artikkeli on ensimmäisiä keskustelunavauksia suomalaiseen meemitutkimukseen ja tarjoaa vain pintaraapaisun meemien analysointiin. Aiheen käsittely on tärkeää remix-kulttuuriin nojaavassa hybridissä mediaympäristössä, jossa verkkojulkisuudet haastavat valtajulkisuutta ja toimivat ennen kaikkea omilla pelisäännöillään. Verkkopropagandassa käytettyjä ilmaisutapoja ammennetaan meemeistä ja viraalisesti leviävistä sisällöistä.

Tässä artikkelissa analysoin kahta suomalaisten nuorten verkkokulttuurissa kiertävää meemiä: Sad Frog ja Liekkipipo ja pirikiikarit. Huumori ja poliittisesti loukkaava sisältö voivat sekoittua nettimeemissä sen kiertäessä transnationaalisti verkossa. Vaikka kumpikaan tässä analysoiduista meemeistä ei ole varsinaisesti poliittinen meemi, olisi niistä mahdollista tehdä poliittisia versioita erilaiseen kontekstiin ja tavoitteisiin yhdistettynä. Tavoitteenani on osoittaa, miten meemien monitulkintaisuus mahdollistaa huumorin lisäksi erilaisten ideologisten sisältöjen kierrättämisen niiden varjolla.

Tämän artikkelin pohdinnan perusteella esitän viisi seikkaa, joita meemejä analysoitaessa tulisi tarkastella. Nämä ovat meemin konteksti, tunnerekisteri, muoto, tavoitteet ja rakennusaineet. Meemin kantaaottavuus syntynee siitä, minkälaiseen kontekstiin se asetetaan. Usein tämä konteksti onkin kulttuurisidonnainen. Verkossa kontekstualisointi ja kuvan tai tekstin tulkinta on erityisen vaikeaa (Hine 2015, 4; Shifman 2014, 150). Meemin esiintymiskonteksti on erityisen tärkeä, koska sama meemi voi eri verkkotilassa merkitä eri asioita. Meemin tunnerekisteri tarkoittaa sitä tunnetta, jota meemi mahdollisesti kuvastaa - esimerkiksi Sad Frog -meemissä tämä tunne on useimmiten suru. Kaikista meemeistä tunnetta ei välttämättä ole edes mahdollista saada selville.

Meemin muodolla viittaan meemilajiin; kuuluuko kuva esimerkiksi johonkin vakiintuneeseen meemityyppiin, kuten esimerkiksi rage-sarjakuviin? Kun erilaisia kuvia ja kansalaisten tekemiä infografiikoita käytetään milloin minkäkin asian perustelemiseen (ks. esim. Sarhimaa 2016), tulee yhä tärkeämmäksi pohtia myös verkossa leviävien kuvien tavoitteita. Voidaan esimerkiksi kysyä, mitä kuvalla pyritään sanomaan tai vihjaamaan tai vaikuttaako kuvan taustalla jokin ideologia. Meemin rakennusaineilla tarkoitan niitä aineksia, joista remix tai kollaasi on tehty. Niiden avulla pystytään jäljittämään sitä kierron prosessia, jonka kautta meemi on muodostunut. Lisäksi meemikuvien analyysissä on tärkeä ottaa huomioon, minkälaista intertekstuaalisuutta meemiin mahdollisesti liittyy. 


\section{Tutkimuskirjallisuus}

Ahmed Sara (2004) The Cultural Politics of Emotion. Edinburgh: Edinburgh University Press.

Appadurai, Arjun (1996) Modernity at Large. Cultural Dimension of Globalization. Minneapolis: University of Minnesota Press.

Aro, Jari \& Sarpavaara, Harri (2007) "Sukupuolistereotypiat sähköpostihuumorissa". Sosiologia vol. 44:3, 191-203.

Auerbach, David (2012) "Anonymity as Culture: A Treatise". Triple Canopy 15. Saatavilla: $<$ https://www.canopycanopycanopy.com/issues/15/contents/anonymity_as_culture_treatise> (linkki tarkistettu 7.9.2016).

Bahtin, Mihail (1995 [1965]) Francois Rabelais - Keskiajan ja renessanssin nauru. Helsinki: Kustannus Oy Taifuuni.

Bernstein, Joseph (2015) “How A Leftist Finnish Meme Became A White Supremacist Comic Strip". Buzzfeed News, <http://www.buzzfeed.com/josephbernstein/how-a-leftist-finnish-memebecame-a-white-supremacist-comic\#.epKX3PeoM5> (linkki tarkistettu: 1.9.2015).

boyd, danah (2008) Taken Out of Context. American Teen Sociality in Networked Publics. Berkeley: University of California, Berkeley.

Brideau, Kate \& Berret, Charles (2014) "A Brief Introduction to Impact: 'The Meme Font"'. Journal of Visual Culture vol. 13:3, 307-313.

Burnett, Gary; Lee, Jisue; Hollister, Jonathan M. \& Skinner, Julia (2014) Information Worlds: Boundaries and Intersections in Three Online Settings. Selected Papers of Internet Research 15: The 15th Annual Meeting of the Association of Internet Researchers. Daegu, Korea, 22-24.10.2014.

Burroughs, Benjamin (2013) "Obama Trolling: Memes, Salutes and an Agonistic Politics in the 2012 Presidential Election". Fibreculture Journal 22.

Chen, Shih-Wen (2014) "Baozou Manhua (Rage Comics), Internet Humour and Everyday Life". Continuum vol. 28:5, 690-708.

Cirucci, Angela (2015) "Redefining Privacy and Anonymity Through Social Networking Affordances". First Monday vol. 20:7.

Coleman, Gabriella (2014) Hacker, Hoaxer, Whistleblower, Spy The Many Faces of Anonymous. Lontoo \& New York: Verso.

Davison, Patrick (2014) "Because of the Pixels: On the History, Form, and Influence of MS Paint". Journal of Visual Culture vol. 13:3, 275-297.

Dawkins Richard (1976) The Selfish Gene. New York: Oxford University Press.

Douglas, Nick (2014) "It's Supposed to Look Like Shit: The Internet Ugly Aesthetic". Journal of visual culture vol. 13:3, 314-339.

Eranti, Veikko (2014) "Sosiaalinen media ja kampanjointitapojen muutos: Pekka Haavisto ja presidentinvaalit 2012". Politiikka vol. 56:2, 101-115.

Esteves, Victoria (2014) “Internet Memes: Transnational Products of (Home-Made) Cyberculture". Julkaisematon tutkimusartikkeli. Saatavilla: <http://www.inter-disciplinary.net/criticalissues/wp-content/uploads/2014/04/estevescyberpaper.pdf> (linkki tarkistettu: 2.9.2015).

Fernback, Jan (2003) "Legends on the Net: An Examination of Computer-Mediated Communication as a Locus of Oral Culture". New Media \& Society vol. 5:1, 29-45.

Gal, Noam; Shifman, Limor \& Kampf, Zohar (2015) “'It Gets Better': Internet Memes and the Construction of Collective Identity". New Media \& Society (ensijulkaisu 27.01.2015).

Haasio, Ari \& Zechner, Minna (2014) "Identiteettipuhetta Hikikomero-keskustelufoorumilla". Teoksessa Mika Gissler, Marjatta Kekkonen, Päivi Känkänen, Päivi Muranen \& Matilda WredeJäntti (toim.) Nuoruus toisin sanoen. Nuorten elinolot -vuosikirja 2014. Helsinki: Terveyden ja hyvinvoinnin laitos, 51-62.

Haasio, Ari (2015) Toiseus, tiedontarpeet ja tiedon jakaminen tietoverkon "pienessä maailmassa". Tutkimus sosiaalisesti vetäytyneiden henkilöiden informaatiokäyttäytymisestä. Acta Universitatis Tamperensis 2081. Tampere: Tampere University Press.

Halmetoja, Jenni (28.2.2015) "Epäkorrektin kieli, suomalaiset meemit". Kieleke Suomen kielen opiskelijoiden lehti. 
Haveri, Minna (2015) "ITE-taiteen hauska brändi". Teoksessa: Seppo Knuuttila, Pekka Hakamies \& Elina Lampela (toim.) Huumorin skaalat Esitys, tyyli, tarkoitus. Kalevalaseuran vuosikirja 94. Helsinki: SKS, 108-124.

Heimo, Anne (2013) "Meemi tulee, folkloristi, oletko valmis? Elore vol. 20 2/2013. Saatavilla: <http://www.elore.fi/arkisto/2_13/heimo.pdf> (linkki tarkistettu 25.5.2016).

Hine, Christine (2015) Ethnography for the Internet. Embedded, Embodied and Everyday. Lontoo: Bloomsbury.

Hokkanen, Laura (2015) "Mustan ja alatyylisen huumorin ilmiöitä 2000-luvun digiloressa". Teoksessa Seppo Knuuttila, Pekka Hakamies \& Elina Lampela (toim.) Huumorin skaalat Esitys, tyyli, tarkoitus. Kalevalaseuran vuosikirja 94. Helsinki: SKS, 362-378.

Horsti, Karina (2016) “Digital Islamophobia: The Swedish Woman as a Figure of Pure and Dangerous Whiteness". New Media \& Society.

Hutcheon, Linda (1995) Irony's Edge. Lontoo \& New York: Routledge.

Jenkins, Henry; Green, Joshua \& Ford, Sam (2013) Spreadable Media: Creating Value and Meaning in a Networked Culture. New York: New York University Press.

Kamppinen, Matti (2002) "Meemit, aika ja ikuisuus - näkökulmia uskontojen ajalliseen sitkeyteen". Tieteessä tapahtuu 8/2002, 62-68.

Kolehmainen, Marjo (2015) Satiiriset Itse valtiaat. Poliittinen huumori suomalaisessa julkisuudessa. Acta Universitatis Tamperensis 2080. Tampere: Tampere University Press.

Kääpä, Pietari \& Jaakko Seppälä (2012a) "Suomalaisen elokuvakulttuurin kansallisuus ja kansainvälisyys". Lähikuva vol. 25:3, 3-7.

Kääpä, Pietari \& Jaakko Seppälä (2012b) "Transnationaali lähestymistapa suomalaiseen elokuvakulttuuriin". Lähikuva vol. 25:3, 8-33.

Lahtinen, Anu (2009) "Conan O’Brien amerikkalaisessa talk show -traditiossa". Lähikuva vol. 22:2, 26-40.

Lankshear, Colin \& Knobel, Michele (2008) "Remix: The Art and Craft of Endless Hybridization". Journal of Adolescent \& Adult Literacy vol. 52:1, 22-33.

Latvala, Pauliina (2015) "Poliittiset henkilökaskut ja vitsit vallan kommentoijina". Teoksessa: Seppo Knuuttila, Pekka Hakamies ja Elina Lampela (toim.) Huumorin skaalat Esitys, tyyli, tarkoitus. Kalevalaseuran vuosikirja 94. Helsinki: SKS, 166-187.

Lehtonen, Mikko (1999) "Ei-kenenkään maalla. Teesejä intermediaalisuudesta". Tiedotustutkimus vol. 22:2, 4-21.

Lehtonen, Mikko (2004) "Suomi on toistettua maata". Teoksessa Mikko Lehtonen, Olli Löytty \& Petri Ruuska (toim.) Suomi toisin sanoen. Tampere: Vastapaino, 121-147.

Lepistö, Onerva (2016) “Muistoja Yksinäisten vuorten kupeesta: tarkastelussa verkon vastakulttuuriset muumiesitykset". Widerscreen 1-2/2016. Saatavilla: <http://widerscreen.fi/numerot/2016-1-2/muistoja-yksinmuumiesitykset/> (linkki tarkistettu: 16.6.2016).

Lessig, Lawrence (2008) Remix: Making Art and Commerce Thrive in the Hybrid Economy. Lontoo: Bloomsbury.

Löytty, Olli (2004) "Suomeksi kerrottu kansakunta". Teoksessa Mikko Lehtonen, Olli Löytty \& Petri Ruuska (toim.) Suomi toisin sanoen. Tampere: Vastapaino, 97-119.

Manivannan, Vyshali (2013) “Tits or GTFO: The Logics of Misogyny on 4chan's Random - /b/". Fibreculture Journal 22.

Marcus, Olivia Rose \& Singer, Merrill (2016) “Loving Ebola-Chan: Internet Memes in an Epidemic". Media, Culture \& Society (ensijulkaisu 25.4.2016).

Miller, Hannah; Thebault-Spieker, Jacob; Chang, Shuo; Johnson, Isaac; Terveen, Loren \& Hecht, Brent (2016) “'Blissfully Happy' or 'Ready to Fight': Varying Interpretations of Emoji”. Julkaisematon tutkimuspaperi. Saatavilla: <http://www-users.cs.umn.edu/ bhecht/publications/ ICWSM2016_emoji.pdf> (linkki tarkistettu: 15.4.2016).

Milner, Ryan (2013) “FCJ-156 Hacking the Social: Internet Memes, Identity Antagonism, and the Logic of Lulz". Fibreculture Journal 22.

Miltner, Kate (2014) “'There's No Place for Lulz on LOLcats': The Role of Genre, Gender and Group Identity in the Interpretation and Enjoyment of an Internet Meme". First Monday vol. 19:8.

Mina, An Xiao (2014) “Batman, Pandaman and the Blind Man: A Case Study in Social Change Memes and Internet Censorship in China". Journal of Visual Culture vol. 13:3, 359-375. 
Molin Friis, Simone (2015) “'Beyond Anything We Have Ever Seen’: Beheading Videos and the Visibility of Violence in the War Against ISIS". International Affairs vol. 91:4, 725-746.

MTV uutiset (15.09.2015) “Some räjähti - tässä hulvattomimmat lakkomeemit”, <http://www. mtv.fi/uutiset/kotimaa/artikkeli/some-rajahti-tassa-hulvattomimmat-lakkomeemit/5311336> (linkki tarkistettu: 18.9.2015).

Nakamura, Lisa (2014) “'I WILL DO EVERYthing That Am Asked': Scambaiting, Digital ShowSpace, and the Racial Violence of Social Media". Journal of visual culture vol. 13:3, 257-274.

Nikunen, Kaarina (2007) "Kompuroivat perheet hajoilevissa taloissaan eli tavallisuuden representaatiot Hauskoissa kotivideoissa". Lähikuva vol. 20:2, 27-45.

Paasonen, Susanna (2011) Carnal Resonance: Affect and Online Pornography. Cambridge, Mass: MIT Press.

Paasonen, Susanna (2014) "Juhannustanssien nopea roihu ja Facebook-keskustelun tunneintensiteetit". Media \& viestintä. Vuosikirja 2014, 176-193.

Rantala, Pälvi (2015) “Huvittava kylähullu”. Teoksessa Seppo Knuuttila, Pekka Hakamies ja Elina Lampela (toim.) Huumorin skaalat Esitys, tyyli, tarkoitus. Kalevalaseuran vuosikirja 94. Helsinki: SKS, 75-94.

Rodley, Chris (2016) “When Memes Go to War: Viral Propaganda in the 2014 Gaza-Israel Conflict". Fibreculture Journal vol. 27, 8.3.2016.

Saarikoski, Petri (2016) '"'Pistä natsi asialle ja mene itse perässä!' Hitler-videomeemien historia ja anatomia". WiderScreen 1-2/2016. Saatavilla: <http://widerscreen.fi/numerot/2016-1-2/pistanatsi-asia-ja-anatomia/> (linkki tarkistettu 26.5.2016).

Sarhimaa, Jutta (3.3.2016) "Ruoasta saa sanoa netissä ihan mitä tahansa, ja tämä suomalaisprofessori on saanut siitä tarpeekseen". Helsingin Sanomat. NYT-liite. Saatavilla: <http://nyt.fi/ a1456972272042> (linkki tarkistettu: 13.4.2016).

Sharma, Sanjay (2013) “Black Twitter?: Racial Hashtags, Networks and Contagion”. New formations vol. 78, 46-64.

Shifman, Limor (2014) Memes in Digital Culture. Cambridge MA: MIT Press.

Suominen, Jaakko; Östman, Sari; Saarikoski, Petri \& Turtiainen, Riikka (2013) Sosiaalisen median lyhyt historia. Helsinki: Gaudeamus.

Uotila, Otto (2013) Anonyymit anarkistit Suomalainen anonyymi verkkokulttuuri Milauta-sivustolla. Pro gradu -tutkielma. Helsinki: Helsingin yliopisto, Valtiotieteellinen tiedekunta.

Urbaanisanakirja (2014) "Liekkipipo", <https://www.urbaanisanakirja.com/word/liekkipipo/> (luettu 13.9.2016).

Uskali, Turo (2013) Obama ja meemit voittivat. Media \& viestintä/Journalismikritiikin vuosikirja (toim. Heidi Kurvinen) vol. 36:1, 163-169.

Vainikka, Eliisa (08.02.2016) "Kuvien kierrosta". Verkkonuorisotyön keskus Verken blogi, $<$ https://www.verke.org/blog/kuvien-kierrosta/> (linkki tarkistettu 30.3.2016).

Valaskivi, Katja \& Sumiala, Johanna (2014) “Circulating Social Imaginaries: Theoretical and Methodological Reflections". European Journal of Cultural Studies vol. 17:3, 229-243.

Vertovec, Steven (2009) Transnationalism. Lontoo, New York: Routledge.

Whelan, Andrew (2013) “EVEN WITH CRUISE CONTROL YOU STILL HAVE TO STEER: Defining Trolling to Get Things Done". Fibreculture Journal vol. 22.

Wiggins, Bradley E. \& Bowers, Bret G. (2015) “Memes as Genre: A Structurational Analysis of the Memescape". New Media \& Society vol. 17:11, 1886-1906.

Wiggins, Bradley E. (2016) "Crimea River: Directionality in Memes from the Russia-Ukraine Conflict". International Journal of Communication vol. 10, 452-485. 